\title{
THE INTEGRATION OF CHARACTERS EDUCATION INTO TEACHING READING HORTATORY TEXT
}

\author{
Meladina \\ STIKES Fort de Kock Bukittinggi \\ meladina@fdk.ac.id \\ Zainuddin Amir \\ STIKES Fort de Kock Bukittinggi
}

\begin{abstract}
Abstrak
Makalah ini memaparkan bagaimana menerapkan character education dalam kelas dengan menggunakan keterampilan membaca teks hortatory. Pada awal pembelajaran, guru memodelkan salah satu karakter yang perlu dimiliki siswa kemudian agar siswa mempunyai kreatifitas dalam berfikir, guru menampilkan sebuah gambar dan meminta pendapat mereka tentang gambar tersebut. Setelah itu, guru memberikan sebuah teks hortatory yang berkaitan dengan gambar dan character education di dalamnya. Guru membimbing siswa untuk bisa memahami isi teks dan berdiskusi tentang apa yang dibahas di dalam teks dengan melibatkan atau memperkenalkan beberapa character education dalam proses pengajarannya. Untuk membuat siswa lebih paham terhadap teks yang mereka baca, guru menyuruh siswa untuk berdiskusi dengan kelompoknya membuat sebuah tulisan tentang kesimpulan dari isi teks tersebut dengan menggunakan bahasa mereka sendiri dan melaporkannya di depan kelas. Selain itu, guru juga dapat memperkenalkan character education tersebut melalui langkah pembelajaran yang diterapkan.
\end{abstract}

Kata Kunci: Character Education, Membaca dan Teks Hortatory

\begin{abstract}
This paper describes how to implement the character education in the classroom by using the reading skill hortatory exposition text. At the beginning of the lesson, the teacher has to model one of the characters that the students have to adopt then to make the students think creatively, the teacher shows a picture and asks them to share their ideas about it. After that, the teacher distributes a hortatory text that related to the picture and consists of character education on it. The teacher guides the students to comprehend the text and discuss what the text tells about. The teacher also introduces some character education on his/her steps of teaching. To make the students more understand about the text, the teacher asks the students to work in pair to make a summary writing about the text and repot it in front of the class.by using their own words.
\end{abstract}

Key Words: Character Education, Reading, Hortatory Text

\section{INTRODUCTION}

Over the last ten years, there are major problems in schools that involve many students in senior high school. It attracts serious attention not only from Indonesian's government but also from teachers at many schools. The problems that involves the students in high school such as fighting between two groups of students that effect at least two students died, do not have responsibility to their duties, do not respect to their teacher for example fighting their teacher back if they do something that teacher do not accept it and try beguile others if they do a mistake or dishonest.

All of those problems above occur because of some factors. First, the students do not have enough attention from their parents at home or on other words they 
come from broken home family. Second, they have financial problems. According to Aristoteles (In Haba 20:5) says that "poverty is the godfather of revolution and criminality". From this statement we can conclude that students from weak financial support often do the criminality or do the bad attitude than those students who have a good financial support. It is because they do not want to live with that shortage and try to find an easy way to get what they want such as stealing her/his friend's right. Poverty or weak financial problem also affects their behaviour, as said in (The Relationship Between Low Family Income and Psychological Disturbance in Young Children: An Australian Longitudinal Study) "Low family income is a significant factor in the etiology of a variety of children behaviour problem" and also in one of the study from Mc Clelland (In Buck, 1988:383) who supported the American's opinion that poverty deals with psychological of an individual. Even many children from poor families get the depression with their condition, and they can't approve that condition. Last, the educator or teacher does not give attention to the students so they are free to do what they want without obeying rules that they have to pay attention. Most of teachers only teach without educating the students. It means that they do not know how to put the value of morality in their teaching.

Actually, to educate students' characters can be implemented in all subjects in teaching learning process especially in teaching language as foreign language. In learning a foreign language such as English, there are many skills that we can use to apply it, for example in reading. Reading is an important skill in leaning a foreign language. By reading, students get information about a knowledge that they do not know before. For example by reading a passage about technology students may know about some technical term that use in that field of study.

In addition, In order to implement character education to the students who lack of morality, attitude and behaviour, teachers may apply some steps of teaching and learning process to create classroom strategies that include character education on it for example when the teacher come to the class they have to create positive moral influence to their students such as respecting and caring about their students, setting a good example, and providing directive moral guidance.

Besides, teachers can also use reading a passage as a medium to educate their students. It means that, teacher choose materials that are related to build students character, ask the students to read it then explore, discuss and ask each student to share their opinion that topic.

In 2013 Curriculum, reading is one of English skills that should be learnt and mastered in any level of education from elementary up to senior high school. According to that curriculum, students at senior high school have to mastered many kinds of texts that consist of twelve genres, such as narrative, descriptive, report, recount, discussion, explanation, hortatory, analytical exposition, news item, review, procedure, and spoof text. In this case, writer decided to choose reading hortatory text that consists of character education's material. It means the teacher chooses a topic that that related with moral value that exists in students' environment and talk about it in a hortatory text. Hortatory text is a text that try influence or persuade the reader about something by presenting the supporting arguments so that the teacher discuses with the students about that topic and share what their opinion about the material. This way is expected to enable the students to make draw a conclusion about the topic and they feel motivated to adapt it in their daily life. So that, indirectly students know moral value that exist in their environment and what attitude is good or not good.

As mentioned in the background of the problem above, most of students in senior high school tend to do some acts that can damage themselves and people around them. This problem occurred because of some factors. First, they do not have enough attention from their parents. Second, is financial problem and the last is the teacher does not find a good way to 
educate the moral value in teaching and learning process.

Because of those problems, the teacher have to give some advices that they may have attention more from a teacher at their school by sharing their problem and financial problem is not a reason for them to do the criminal act. They can learn from the environment to change their life by seeing the environment as a positive place to develop their capabilities to make their life much better. Besides, the teacher also has to educate the characters' of the students by practicing it in teaching and learning process and also giving some materials that involve the cultivation of virtue that exist in their environment then shows in hortatory text.

The purpose of this article is to describe how to integrate character education into teaching reading hortatory text. In this article, the writer also explains the stages of teaching English as second language that involve character education on it.

Character education is a process to educate people to adapt some characters that will be used in their daily life so that they will be accepted by people around them. It is supported by Likona in Reigeluth (1991:594) who states that character education is a deliberate effort to help people understand others, care about, and act upon core ethnic value. He also asserts that when we teach about the kind of character for our children, it is clear that we want them to be able to judge what right, care deeply what is right, and do what they believe to be right.

Hilgard's \& Atkinson (2006:2) state that character education is an effort to create a nation that has many schools that foster and caring young people by modeling and teaching good character through an emphasis on universal values that educator all share. It is the intentional, proactive effort by schools, districts, and states to instill in their students important core, ethical values such as respect for self and others, responsibility, integrity, and selfdiscipline. It means that, character education needs long terms solution in learning and teaching it because it focus on moral, ethical, and academic issues that concern of the society and the safety of a school and also critical concern by students itself.

According to Smith (2002) there are some traits that will be learned in character education classroom. They are as follow:

Responsibility

Responsibility is the basic belief that each of us has a mutual agreement with those around us to do our part, to carry our fair share of the load and to accept the consequences of our actions.

Honesty

Honesty is telling the truth - in other words, conforming our words to reality. Integrity

Integrity is conforming our reality to our words - in other words, keeping promises and fulfilling expectations.

Respect

Respect is based on the social groups believe in religions and culture for example respect for self and others, for example, toward the elders as the keepers of wisdom, toward families as preservers of traditions, and toward individuals as members of the group.

Caring

Caring is showing understanding of others by treating them with kindness, compassion, generosity, and a forgiving spirit.

Moreover, Isaacs in Reigeluth (1991:598) offers a more elaborate scheme: 24 virtues, grouped according to developmental periods during which the different virtues should given special emphasis: (a) Up to 7 years: obedience (respecting legitimate authority and rules), sincerity (truth telling with charity and prudence), and orderliness (being organized and using time well); (b) from 8 to 12 years; fortitude, perseverance, industriousness, patience, responsibility, justice, and generosity; (c) from 13 to 15 years: modesty (respect for one's own privacy and dignity and that of others), moderation (self-control), simplicity (genuineness), sociability (ability to communicate with and get along with others), friendship, respect, patriotism (service to one's country and affirmation of 
what is noble in all countries); and (d) From 16 to 18 years: prudence, flexibility, understanding, loyalty, audacity (taking risk for good), humility (self-knowledge), and optimism (confidence).

Besides, Harris and Sipay (1980:23) state that reading is meaningful interpretation of written verbal symbol. It is a result of the interaction between the perception of graphic symbols that represent language and readers' skills and knowledge of the word. It means that, reading the interpretation of a written symbol into meaningful perception that consists of many reading skills and knowledge of the readers.

Related to the definition above, Silberstein (1987:7) defines reading as an active cognitive process of interacting with printed symbol to establish meaning. Moreover, he explains reading as meaningful interpretation of printed or written symbol. Thus, the reader should be able to acquire such as idea from the text to he reads. Reading is instantaneous association of these symbols with existing knowledge and comprehension of the information or ideas communicated.

Reading involves the reader, the text, and the interaction between reader and text. Reader's engagement in the reading process is based on their part experience, both and learning how to read and also in the ways reading fits into their lives (Aebersold 1997:5). In the same way Anderson (1999:1) says that reading is an active, fluent process which is involves the reader and the reading material in building meaning. Hence, reading is consists of many element that makes to achieve the goal of reading itself such as interaction between reader and text, experience, and the materials of the text that will be read.

One of genre of the text that has to be taught in senior high school is hortatory exposition text. According to Gerot and Wignell (1994:209), hortatory text is a kind of text that used to persuade the reader or listener that something should or should not be the case. In the same way Hartono (2005:6) says that hortatory exposition text is a factual genre text that has social function to persuade the reader or listener that something should or should not be case. In other word, hortatory text is a kind influencing text which tries to convince the reader or listener to do or not to do base on the writer's arguments.

In teaching English, there are four competencies that students should be mastered one of them is reading. According to Crandall (in Byrd, 1995), there are some stages that involve in teaching reading:

Pre-reading activities

This stage is an activity to recall the students' background knowledge to make students familiar with the text and make the students motivated to read the text. Discussion, pre-question and are some activities which can involve in this stage as a way to help relate the reading to students' prior experiences, activating students' schemata, and building vocabulary. The aim of these activities is to develop students' interest to the topic. The teacher also could help the students to identify the cultural influences that may affect the reading comprehension.

Whilst-reading activities

In this step, the teachers with the students together begin reading the text. The teacher and students can discuss about generic structure, schematic structure, lexico-grammatical features and linguistic features of the text. The teacher also can use a variety of technique which reflect the logical relation between the ideas in the text and encourage students to react and reflect upon what they read.

Post-reading activities

Post-reading activities provide an opportunity for synthesis and evaluation. In this step, the teacher can encourage the students to reread the segment of the text. In order to measure the students' comprehension, the teacher can provide some activities. For example: application activities, such as journal writing, presentation in front of the class, or question-answer activities. 


\section{DISCUSSION \\ Preparation}

There are many preparations that should be done by the teacher before $\mathrm{him} / \mathrm{her}$ going to teach such as:

Choosing the hortatory text

There are many criteria of hortatory text that the teacher should pay attention before she/he wants to bring to the classroom. First, the hortatory text should consist of virtue that exists in students' environment such as responsibility in students' life, caring to others and etc. By doing that, the students will easy to understand that topic discussed. Second, it should motivate the students to adopt that kind of virtue in their daily life. Third, the hortatory text should appropriate with students level of understanding. Last, the language that used in hortatory text is easy to understand by the students.

Lesson plan

Lesson plan is the important part that the teacher has to prepare before she/he comes to the class. It is such a guideline for the teacher about what she/he does in a classroom. It also reminds the teacher if there is something missing when she/he teaches and make teaching and learning process can run systematically.

\section{The Procedure of Integrating of Character Education into Teaching Reading Hortatory Text \\ Pre-Teaching Activities}

The teacher checks the students' attendance and asks their condition on that day (caring to the students).

The teacher allows the students to share what they feel about their lesson for about five minutes. By doing those activities the students feel comfortable and feel closer to the teacher.

Before the teacher comes to the material, she/he may take some steps to create a caring classroom community by helping students to know each other as person; respect, care about, and affirm each other; and feel a valued membership in the group in five minute. Those can be done by doing three simple things. First, the teacher asks the students to share their good news such as their birthday party, their achievement in the school and many things that can make them happy after experienced it. After a few students share good news, the teacher may ask "Would anyone like to affirm anyone else?" It is believed that the students become comfortable doing that. Finally, the teacher may ask the students to seat different from the one they had in the previous class and take a minute to get to know their new neighbor better.

The teacher may come to the material that related to caring others by showing the picture below. The teacher asks the students to share their opinion about that picture (creative thinking) and remains the students to listen what their friends talk about carefully (respect each other).

The teacher tells to the students about the title of the text that they are going to read. In this section the teacher tells the students that they are going to read a hortatory text with the title caring to others. Then, the teacher asks what comes to your mind when you heard the word "care" (critical thinking and creative thinking), work with your partner discuss about what do you think about that word (team work and respect each other).

The teacher asks the students to predict what the text is about (creative thinking). The students are free to make a prediction or what they are thinking about the title of the text and they have to write their questions in a piece of paper about the text that they are going to read and what they want to know about the text (creative thinking and critical thinking).

\section{Whilst-Teaching Activities}

The teacher distributes a hortatory text about caring to others.

The teacher asks the students to read whole text individually and try to scan the questions that have already risen in the previous stage in five minutes (fortitude and critical thinking).

The teacher tells to the students to focus on the first paragraph, reads the first paragraph and asks whether they understand it or not. If the students do not understand, the teacher may help them (caring to the students). 
The teacher and the students discuss about the main idea of that paragraph together (respect each other).

The students have to continue to read whole text in small group and try to find the answer of their questions (critical thinking, team work and respect each other). If their question did not include in the text, the teacher discuss the reason why the author did not include it.

The teacher asks the students to pay attention to each words, phases, and sentences. They have to understand about the topic sentence, main idea, synonym, reference and many others that can help them to understand and comprehend the text (fortitude).

The teacher gives an exercise to the students. Before the students do the exercise, the teacher remains the students do not cheat (honesty), do the exercise by themselves and the time for about 30 minutes (independent, fortitude, and critical thinking).

\section{Post-Teaching Activities}

The teacher asks the students to work in pairs to make summary writing about the topic that they have already read

The teacher asks each of group report their discussion in front of the class (respect each other, group work, creative thinking and self confidence)

\section{The Advantages of Integration of Character Education into Teaching Reading Hortatory Text}

There are several advantages that a teacher can get if he/she integrates character education into teaching reading hortatory text. First, by integrating character education in reading, the teacher will get two profits. Besides he/she teach how to understand a text, he/she also teach about morality to the students so they will know and get a new point of view about that even their attitude can be change after that.

Second, hortatory text makes the students think creatively and critically to solve the problem. Third, on hortatory text the students are influenced to do or not to do something. Means, they have to do or not to do something based on the writer arguments.

Last, through discussion in classroom the students able to socialize with their friends. They are ready to get a critique and suggestion from their friends and also want to accept others opinion and also know how to ignore it in the best way.

\section{CONCLUSION}

Character education is a process to educate the students to adopt some good characters in their daily life. By adopting those characters the students can be accepted by people around them. There are some ways in implementing character education in teaching and learning process in the school. One of them is in teaching reading hortatory text. Based on the discussion on the previous chapter, it can be concluded that in implementing character education into teaching reading hortatory text, the teacher has to model the character education in the beginning of the lesson. Then, the teacher creates the students' creative thinking by showing a picture. The students have to share their opinion about the picture. After that, the teacher distributes a hortatory text about character education and the students and the teacher discuss the text together to make the students comprehend the text and take many lessons about character education from that text. At the end of the lesson, the teacher asks the students to work in pairs to make a summary writing about the text and repot it in front of the class. Besides, the teacher shows or introduces the character education to the students in her/his step of teaching and the teacher has to encourage the students that the good virtues are very important to make a better life.

There are many advantages that can be gotten by the teacher and the students in integrating character education in reading hortatory for example comprehend the text, take many lessons from the text that they read, think creatively and critically when they ask to solve a problem.

There are several suggestions to the teacher in integrating character education into teaching reading hortatory text: (1) The teacher has to pay attention to the text that 
he/she going to teach in the classroom. They have to choose the right text and will motivate the students to adopt the character that explain on the text, (2) In the step of teaching, the teacher should be creative to guide the students to do what the teacher wants to do and at the end of the lesson the

\section{REFERENCES}

Aebersold, Jo Ann and Mary Leefield. 1997. From Reader to Teacher. New York: Cambridge University Press

Anderson, Neil. 1991. Exploring Second Language Learning: Issue and Strategy. Unites States: Heinle \& Heinle; 1 st edition.

Buck. Roger W. 1988. Flexural Rotation of normal faults. New York: Cambridge University Pres.

Haba, John. Nov- Des 2005. Kemiskinan, Status Sosial Yang Didambakan? Suara Pembaharuan dalam Dokumentasi Kliping Situasi dan Arah Kependdudukan Indonesia, Bidang Penelitian dan Informasi Kependudukan Lembaga Demografi Fakultas Ekonomi Universitas Indonesia, XVI:14-15. teacher has to encourage the students to adopt the virtues that have already introduced, (3) The teacher is able explore the text well and modeling the virtues so that the students will understand and feel motivate to imitate it.

Gerot, Linda and Wignell, Peter. 1994. Making Sense of Functional Grammar. Sydney: Gerd Stabler.

Harris, Albert J and Edward Sipay. 1980. How to Increase Reading Ability. New York: Longman Inc.

Hilgard's \& Atkinson. 2006. Introduction to Psychology. United Kingdom: North Way, Andevor, Hampshire.

Hartono, Rudi. 2000. Genre of Text. Solo: UNNES Press.

Reigeluth, Charles M. 1999. InstructionalDesign Theories and Models. London: Lawrence Erlbaum Associates.

Silbersten. 1987. Schemata Theory and ESL Reading Pedagogy in Mythology in TESEL. New York: New York Burry House Publisher.

Smith, Carl B. 2002. Developing Character through Literature. Indiana: ERIC Clearingho 